\title{
Synthesis of New Carbohydrate Derivatives Via 1,3-Dipolarcycloaddition Reaction
}

\author{
A. Hussain K. Sharba*, Yousif A. Al-Fattahi** and Firyal W. Askar ${ }^{*}$ \\ Department of Chemistry, College of Science, Al-Mustansirya University, \\ Baghdad-Iraq. \\ * Department of Chemistry, College of Science, Baghdad University, Baghdad-Iraq.
}

Author to whom correspondence should be addressed ; E-mail: hussainirk@yahoo.com.

\begin{abstract}
This work describes the synthesis of a new fructofuranosyl derivatives comprising 1,2,3triazole, 1,2,3-triazoline or tetrazole rings via 1,3-dipolar cycloaddition reaction. To obtain these derivatives, $1,3,4,6$-tetra- $O$-benzoyl- $\beta$-D-fructofuranose (1) with free hydroxyl group at position-2 was prepared as the starting material. Reaction of compound (1) with $45 \% \mathrm{HBr}$ solution in glacial acetic acid gave compound (2). The bromide (2) was then made to react with some nucleophiles $\left(\mathrm{NaN}_{3}\right.$ and $\left.\mathrm{KCN}\right)$ to give 1,3,4,6-tetra- $O$-benzoyl- $\beta$-D-fructofuranosyl azide (3) and 1,3,4,6-tetra$O$-benzoyl- $\beta$-D-fructofuranosyl cyanide (4). Treatment of compound (3) with cinnamic acid, cinnamaldehyde, acrylic acid, acrylonitrile, acrylamide and maleic anhydride, gave the triazoline derivatives (5-10). Cycloaddition reaction was also carried out with propargyl chloride, propargyl alcohol and 1-hexyn-3-ol using $\left(\mathrm{ph}_{3} \mathrm{P}\right)_{3} \mathrm{CuI}$ as a catalyst to give the triazole derivatives (12-14). Reaction of the cyanosugar (4) with arylsulfonyl azides gave the tetrazole derivatives (16-18). Antibacterial and antifungal activities of some novel synthesized compounds were studied and compared with that of two well known antibiotics (Ampicillin and Gentamycin).
\end{abstract}

\section{Introduction}

In various publications it was found that 1,2,3-triazoles posses therapeutic values [1-3], they are synthetic intermediates in the preparation of medicinal compounds, and find numerous applications in the chemical industry [4]. Some 1,2,3-triazole derivatives have antibacterial [5], antifungal [6], antiviral [7], and anti-inflammatory activities [8]. Other 1,2,3-triazoles can be used as corrosion inhibitors $[9,10]$.

Recently, 1,2,3-triazole links have emerged as a popular bridging units in carbohydrate chemistry because of the facile efficient method of their introduction, which referred to as "click chemistry". The later method is based on $\mathrm{Cu}(\mathrm{I})$-catalyzed version of Huisgen's 1,3-dipolarcycloaddition of azido sugar to terminal alkynes and it has been successfully applied for the synthesis of various glycoconjugates including multivalent glycosides [11].

The development of tetrazoles chemistry has been largely associated with a wide scale of applications for these compounds in medicine, biochemistry [12], agriculture, photography as well as robust binder system for high energy explosives [13].

Tetrazole compounds have also been employed as antibacterial [14], antiviral [15], antifungicial, and anticonvulsive agents [16].

Hydrolysis of the benzoate groups of some novel compounds afforded a new carbohydrate derivatives containing 1,2,3-triazoline and 1,2,3-triazole, and such derivatives are expected to have high solubility in water and may possess biological activity.

The presence of carbohydrate moiety side chain in drug may also overcome the frequently observed water insolubility problem, [17].

The activities were determined in vitro using disc diffusion method against staphaureus, Eschericha coli and three pathogenic strains of yeast (Candida) and fungus (Aspergillus flaveus and pencillium spp.) 


\section{Results and Discussions}

Three types of new sugar-based monocyclic triazole, triazoline and tetrazole derivatives of D-fructose have been synthesized and characterized. These compounds have been synthesized using [3+2] cycloaddition reaction. The reaction sequences are outlined in Schemes (1 and 2) from fructose:

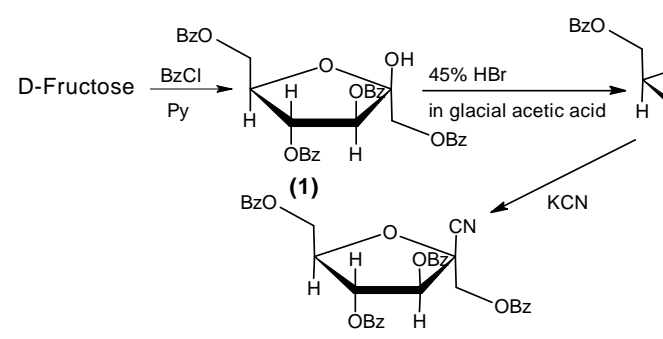

(4)

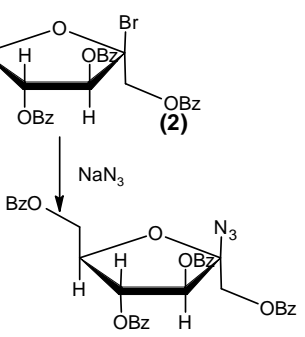

(3)

(3)

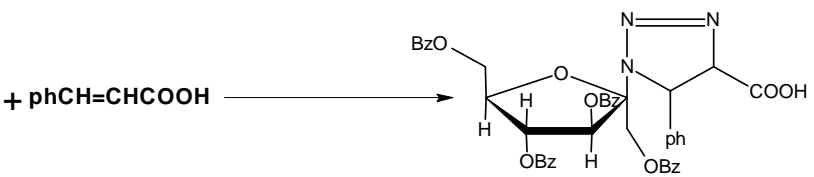

(5)

(3) $+\mathrm{phCH}=\mathrm{CHCHO}$

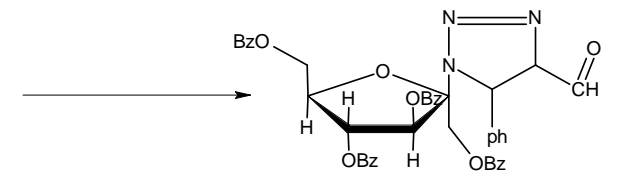<smiles>O=C(O)C=C[18OH]</smiles>

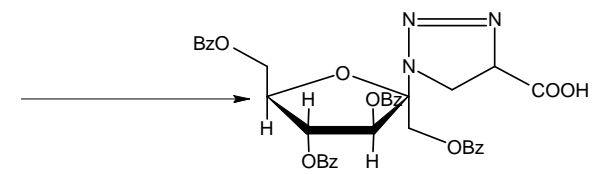

(3)

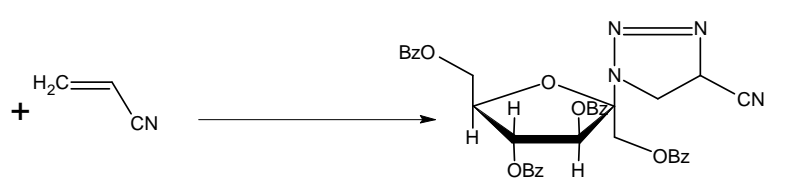

(3)<smiles>C=CC(N)=O</smiles>

(3)

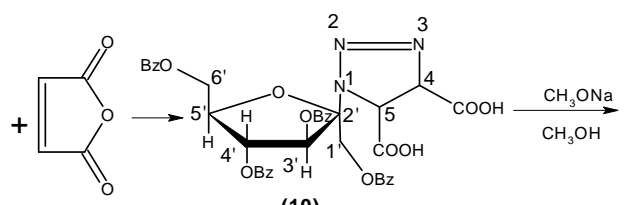

(10)

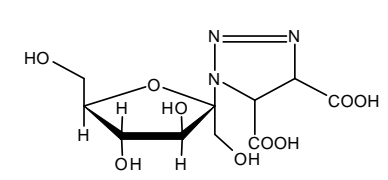

(11)

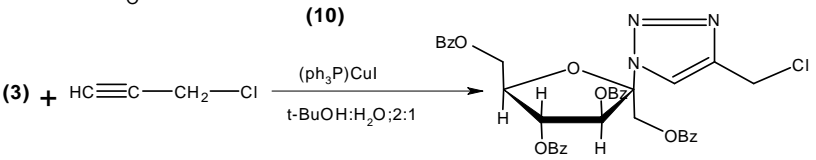

(12)

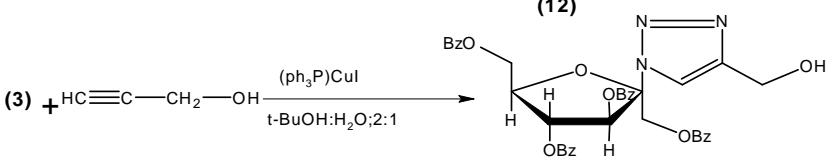

(13)

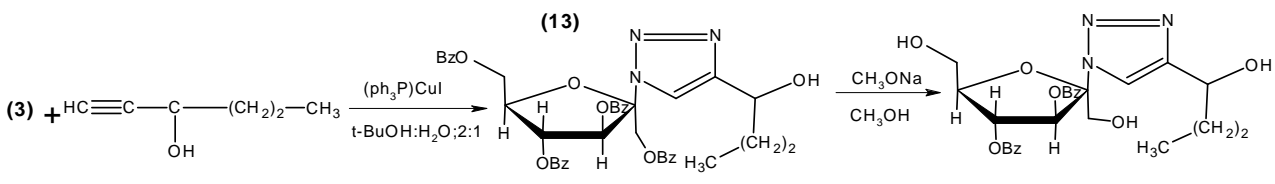

Scheme (1). 

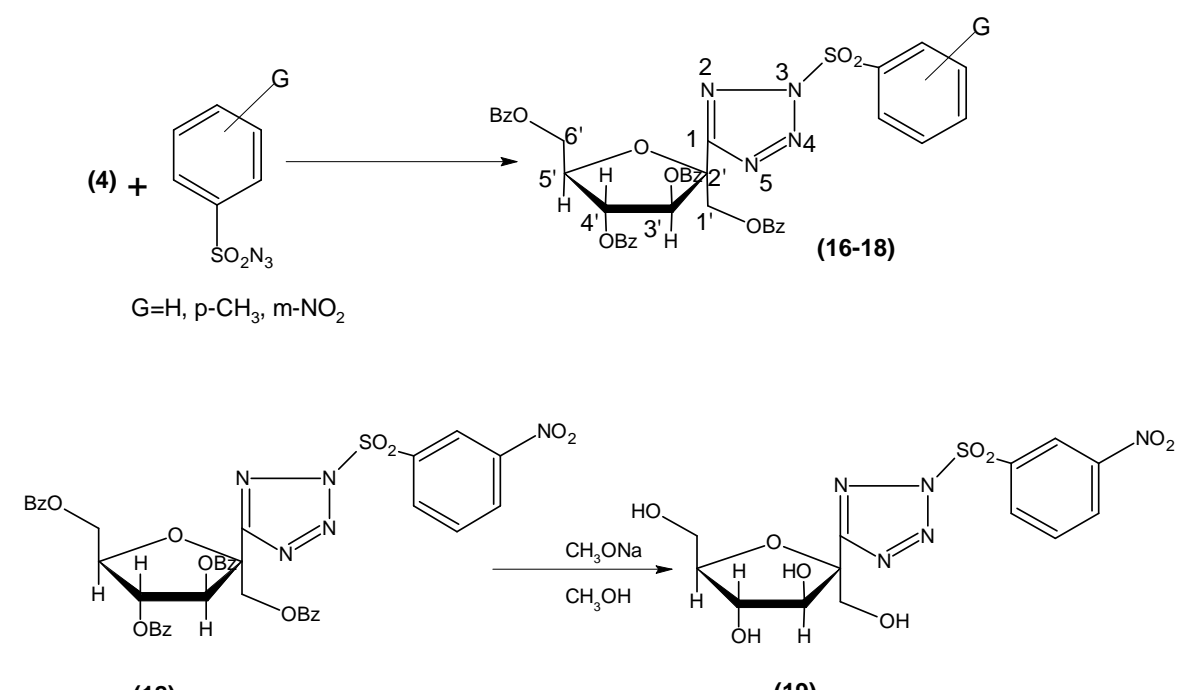

(18)

(19)

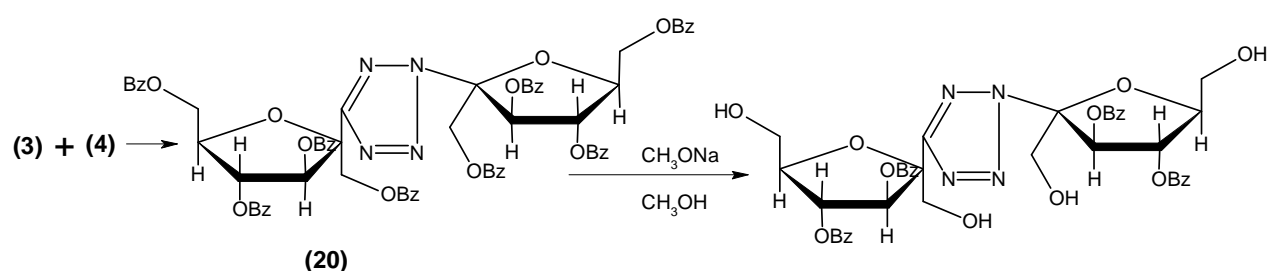

(20)

(21)

Scheme (2).

D-Fructose was first converted to $1,3,4$, 6-tetra- $O$ - benzoyl- $\beta$ - D- fructofuranose (1). According to reported method [18] when compound (1) was treated with $45 \% \mathrm{HBr}$ solution in glacial acetic acid it gave 1,3,4,6tetra- $O$-benzoyl- $\beta$-D-fructofuranosyl bromide (2). Treatment of the benzoylated bromide with sodium azide afforded sugar azide (3). The FTIR spectrum of (3) showed stretching band at $2137 \mathrm{~cm}^{-1}$ indicating the presence of an azido group with disappearance of the (C-Br) stretching band at $650 \mathrm{~cm}^{-1}$.

To prepare the 1,2,3-triazoline derivatives, the azidosugar (3) entered 1,3cycloaddition reaction with cinnamic acid, cinnamaldehyde, acrylic acid, acrylonitrile, acrylamide and maleic anhydride, which gave the triazoline derivatives $(5-10)$ as indicated by the disappearance of $\left(\mathrm{N}_{3}\right)$ vibration band. The FTIR spectrum of (5) showed a characteristic band at $3450-3000 \mathrm{~cm}^{-1}$ due to hydroxyl group of the carboxylic acid, while compound (8) showed a stretching band at $2220 \mathrm{~cm}^{-1}$ for the nitrile group and compound (9) showed a split broad band at $3354 \mathrm{~cm}^{-1}$ and at $3199 \mathrm{~cm}^{-1}$ which was assigned to the asymmetric and symmetric stretching bands of $\mathrm{NH}_{2}$ function, [19]. The ${ }^{1} \mathrm{H}-\mathrm{NMR}$ spectrum of compound (9) showed the signals at $\delta$ 5.85$6.05 \mathrm{ppm}$ assigned to protons of $\mathrm{NH}_{2}$. Proton for triazoline ring $\mathrm{H}-5$ appeared at $\delta 2.89 \mathrm{ppm}$.

The FT-IR spectrum of compound (10) showed a broad stretching band at 3600$3200 \mathrm{~cm}^{-1}$ due to the hydrogen bonded of acid hydroxyl group. FT-IR data gave good evidence that the cyclic anhydride has undergone ring opening during work up to give dicarboxylic acid. Furthermore, the ${ }^{1} \mathrm{H}-\mathrm{NMR}$ spectrum showed a signal at 10.5 ppm and ${ }^{13} \mathrm{C}-\mathrm{NMR}$ spectrum showed a signal at $170.2 \mathrm{ppm}$ indicating the presence of carboxylic acid.

The 1,2,3-triazoles (12-14) were successfully obtained via cycloaddition reaction of the azido sugar (3) with propargyl chloride, propargyl alcohol and 1-hexyn-3-ol using $\left(\mathrm{ph}_{3} \mathrm{P}\right)_{3} \mathrm{CuI}$ as catalyst. The thermal reaction leads to the formation of the disubstituted triazole isomers and need long reaction time while the copper (I)-catalyzed reaction selectively produces the 1,4-isomer in high yields. This assignment is quite compatible with the reported results of Rostovtsev and his co-workers on the addition of benzyl azide to phenyl propargyl ether, [20]. 
FT-IR spectrum of the triazole (13) showed stretching bands at $3400 \mathrm{~cm}^{-1}$ for the $(\mathrm{OH})$ and the disappearance of $\left(\mathrm{N}_{3}\right)$ band at $2137 \mathrm{~cm}^{-1}$. Using nitrile group as a dipolarophile the sugar substituted nitrile (4) readily participated in a $[2+3]$ cycloaddition reaction with arylsulfonyl azide as 1,3-dipole, yielding five membered heterocyclic tetrazole systems. The IR absorption bands were utilized to characterize specific structure for compounds (16-18). The disappearance of the bands at $2200 \mathrm{~cm}^{-1}$ and $2137 \mathrm{~cm}^{-1}$ attributed to nitrile group and azide group stretching frequency is good evidence for the success of this reaction. In addition the IR spectrum of compounds (16) showed a stretching bands at $1610 \mathrm{~cm}^{-1}$ for $(\mathrm{C}=\mathrm{N})$, at $1370 \mathrm{~cm}^{-1}, 1160 \mathrm{~cm}^{-1}$ for $\left(\mathrm{SO}_{2}\right)$, at $1135 \mathrm{~cm}^{-1}, 1085 \mathrm{~cm}^{-1}, 1030 \mathrm{~cm}^{-1}$ for tetrazole ring [21] and at $750 \mathrm{~cm}^{-1}$, $690 \mathrm{~cm}^{-1}$ for mono substituted benzene ring.

The ${ }^{1} \mathrm{H}-\mathrm{NMR}$ spectrum of (17) showed a singlet at $\delta 2.4$ integrated for three protons assigned to p-methyl group, while ${ }^{13} \mathrm{C}$-NMR spectrum showed signal at $20.5 \mathrm{ppm}$ for methyl group of $\mathrm{p}$ - toluene. The signal at 151.3 assigned for $\mathrm{C}=\mathrm{N}$, while the carbonyls of the benzoate appeared at 165, 166, 166.5 and $167 \mathrm{ppm}$. The tetrazole (20) can be synthesized directly by a [3+2] dipolar cycloaddition between an azido sugar (3) and cyano compound such as (4). This reaction occurs through concerted and regioselective [22] cycloaddition with the formation of 2,5disubstituted product as expected.

The IR spectrum of (20) showed the absence of the stretching bands for $(\mathrm{CN})$ at $2200 \mathrm{~cm}^{-1}$ and for $\left(\mathrm{N}_{3}\right)$ at $2137 \mathrm{~cm}^{-1}$ confirmed the formation of the tetrazole (20) with the appearance of band $1610 \mathrm{~cm}^{-1}$ for $(\mathrm{C}=\mathrm{N})$ of the tetrazole ring.

Treatment of the some benzoylated sugar with catalytic amount of sodium methoxide under reflux afforded the free heterocyclic derivatives $(11,15,19$, and 21). The IR spectrum of (11) showed stretching band at $3300 \mathrm{~cm}^{-1}$ for hydroxy groups, while the UV $\left(\mathrm{H}_{2} \mathrm{O}\right)$ spectrum agreed with free deblocked sugar (11), since the $\lambda_{\max }$ at $233 \mathrm{~nm}$ due to $\pi-\pi^{*}$ transition of the benzoate group was absent.

\section{Biological Screening: Antimicrobial Activity Tests}

The biological activity of some of the prepared compounds was tested against one strain of Gram +ve bacteria (Staphylococcus aurous), Gram -ve bacteria (Eschericha coli), yeast (Candidas) and fungi (Aspergillus flavus).

Disc sensitivity test [23] was employed for the in vitro study for anti bacterial and anti fungal studies. This method involves the exposure of the zone of inhibition toward the diffusion of microorganism on agar plate. The plates were incubated for $24 \mathrm{hrs}$. at $37{ }^{\circ} \mathrm{C}$, the zone of inhibition of bacterial growth around the disc was measured.

In order to complete this study, some of the new compounds were tested for their in vitro growth inhibitory activity against yeast (Candidas) and a pathogenic fungi i.e. Aspergillus flavus, Penicillum spp on potato dextrose agar medium, then incubated at $30{ }^{\circ} \mathrm{C}$ for $72 \mathrm{hrs}$. The resulted are presented in Table (1), all tested compounds were less active than Ampicilline and Gentamycine against the Gram positive staphy. aurous. Compounds (11, 12, 18, and 21) were nearly as active as the antibiotics against the Gram negative E. Coli with (21) being the most active. Moreover compounds $(11,12,15$, and 21) show similar activity against the yeast (Candidas) as two antibiotics taken as standard for comparision. Compounds $(12,15,16,18$, and 21) were more active than Ampicilline and Gentamycine against the pathogenic fungi Spergillus flavus, while compounds $(11,15$, and 21) were more active against pencillum spp than the two antibiotics. 
Table (1)

Results of antimicrobial activities of the compounds $\left(10^{-3} \mathrm{mg} . \mathrm{mL}^{-1}\right)$.

\begin{tabular}{|c||c||c||c||c|c||}
\hline Compound & Staph. Aurous & E. Coli & Candidas & Asp. flavus & Penici. spp \\
\hline \hline Control (DMSO) & - & - & - & - & - \\
\hline Ampicillin & 17 & 24 & 20 & 10 & 22 \\
\hline \hline Gentamycin & 20 & 22 & 22 & 17 & 24 \\
\hline 6 & - & 8 & 10 & 10 & 20 \\
\hline 11 & 8 & 20 & 20 & 17 & 19 \\
\hline 12 & 10 & 20 & 20 & 20 & 30 \\
\hline 15 & 10 & 15 & 20 & 20 & 25 \\
\hline 16 & 8 & 15 & 15 & 20 & 22 \\
\hline \hline 18 & 10 & 20 & 15 & 15 & 20 \\
\hline \hline 19 & 8 & 15 & 15 & 20 & 20 \\
\hline \hline
\end{tabular}

Where:

$\begin{array}{ll}\text { 6-8 } \mathrm{mm}:(+) & 10-20 \mathrm{~mm}:(+++) \\ 8-10 \mathrm{~mm}:(++) & 20-30 \mathrm{~mm}:(+++)\end{array}$

\section{Experimental}

\section{General:}

Melting points were recorded using Electrothermal 9100 melting point apparatus and are uncorrected. The IR spectra ( $\mathrm{KBr}$ discs or thin films) were recorded on a Perkin-Elmer 1310 infrared spectrophotometer, or a Shimadzu FTIR-800.

UV spectra were recorded on UV-Visible Varian UV-Cary-100 spectrophotometers. ${ }^{1} \mathrm{H}-\mathrm{NMR}$ and ${ }^{13} \mathrm{C}-\mathrm{NMR}$ spectra were recorded on Varian Gemini 200BB spectrometer $(200 \mathrm{MHz})$ in Lodz University, Poland, on a Bruker-300 at $300 \mathrm{MHz}$ for proton nucleus and $75 \mathrm{MHz}$ for carbon nucleus in Al-Albait University, Jordan and on a $400 \mathrm{MHz}$ in Hanover University, Germany. Tetramethylsilane was used as an internal reference and $\mathrm{CDCl}_{3}$ as solvent. (TLC) was performed on aluminum plates precoated with silica-gel $\mathrm{f}_{254}$, supplied by Merck. Column chromatography was carried out with silica-gel 60 (Fluka). Spots were detected with iodine vapor.

\section{Synthesis of Compounds}

Preparation of 1,3,4,6-Tetra-O-benzoyl- $\beta$-Dfructofuranose (1), [18]:

Anhydrous D-fructose (2g, $11.11 \mathrm{mmol})$ was suspended in a mixture of dry $\mathrm{CH}_{2} \mathrm{Cl}_{2}$ $(30 \mathrm{~mL})$ and dry pyridine $(5 \mathrm{~mL})$. To this mixture benzoyl chloride $(7 \mathrm{~mL})$ was added dropwise, then was heated with continuous stirring for $4 \mathrm{hrs}$, at $\left(55-60{ }^{\circ} \mathrm{C}\right)$. TLC $\left[\mathrm{CH}_{2} \mathrm{Cl}_{2}: \mathrm{MeOH} ; 8: 2\right]$ indicated completion of the reaction. The mixture was poured over icewater then extracted with $\mathrm{CH}_{2} \mathrm{Cl}_{2}(3 \times 15 \mathrm{~mL})$. The organic phase was washed with $(10 \mathrm{~mL})$ $(5 \% \mathrm{HCl})$ solution and then with $\left(5 \% \mathrm{Na}_{2} \mathrm{CO}_{3}\right)$ solution $(10 \mathrm{~mL})$. The $\mathrm{CH}_{2} \mathrm{Cl}_{2}$ layer was dried with anhydrous sodium sulphate and the solvent was evaporated to dryness in vacuo to give a syrup that crystallized from absolute ethanol to give white crystals $(5.1 \mathrm{~g}, 77 \%$ yield), m.p. (121-122 $\left.{ }^{\circ} \mathrm{C}\right)$, lit.[18] (122$\left.123{ }^{\circ} \mathrm{C}\right)$, IR (KBr disc) $3450 \mathrm{~cm}^{-1}(\mathrm{OH})$, $1710 \mathrm{~cm}^{-1}(\mathrm{C}=\mathrm{O})$. 
Preparation of 1,3,4,6-Tetra-O-benzoyl- $\beta-D$ fructofuranosyl bromide (2), [24]:

Glacial acetic acid $(5 \mathrm{~mL})$ was added to a solution of tetrabenzoyl fructofuranose (1) (2g, $3.36 \mathrm{mmol})$ and (45\%) hydrogen bromide in glacial acetic acid $(5 \mathrm{~mL})$. The mixture was stirred for $30 \mathrm{~min}$. and left for $6 \mathrm{hrs}$. at room temperature, after that the mixture was left to stand at $\left(5^{\circ} \mathrm{C}\right)$ overnight. The reaction was monitored by TLC $\left[\mathrm{CHCl}_{3}: \mathrm{MeOH} ; 8: 2\right]$ and the mixture was then neutralized with saturated aqueous sodium bicarbonate solution and extracted with $\mathrm{CH}_{2} \mathrm{Cl}_{2}$ $(3 \times 15 \mathrm{~mL})$. The combined extracts were dried with anhydrous sodium sulphate, filtered and evaporated to dryness in vacuo to give a brown syrup (1.5 g, 66\% yield), IR (film) $1720 \mathrm{~cm}^{-1}(\mathrm{C}=\mathrm{O}), 650 \mathrm{~cm}^{-1}(\mathrm{C}-\mathrm{Br})$.

Preparation of 1,3,4,6-Tetra-O-benzoyl-2azido-2-deoxy- $\beta$-D-fructo-furanose (3):

Compound (2) (1 g, $1.48 \mathrm{mmol})$ and excess of sodium azide were added to DMF $(20 \mathrm{~mL})$. The mixture was heated with stirring at $\left(50-60{ }^{\circ} \mathrm{C}\right)$ for $20 \mathrm{hrs}$. The reaction was monitored by TLC [Benzene:MeOH; 8:2]. The reaction mixture was poured onto icecold water and extracted with chloroform $(3 \times 15 \mathrm{~mL})$, then dried with anhydrous sodium sulphate. The solvent was evaporated to give a syrup $(0.8 \mathrm{~g}, \quad 86 \%$ yield $), \quad \mathrm{R}_{\mathrm{f}}=0.6$ [CHCl $: \mathrm{MeOH} ; 8: 2]$, FTIR (film) $2137 \mathrm{~cm}^{-1}$ $\left(\mathrm{N}_{3}\right), 1720 \mathrm{~cm}^{-1}(\mathrm{C}=\mathrm{O})$.

Preparation of 1,3,4,6-Tetra-O-benzoyl-2cyano-2-deoxy- $\beta$ - $D$-fructofuranose (4):

To a solution of compound (2) $(1 \mathrm{~g}, 1.48$ mmol) in $\mathrm{CHCl}_{3}(30 \mathrm{~mL})$, potassium cyanide $(0.3 \mathrm{~g})$ and tetrabutylammonium iodide $(0.1 \mathrm{~g})$ were added. The resulting mixture was refluxed with continuous stirring overnight. TLC $\left[\mathrm{CHCl}_{3}: \mathrm{MeOH} ; 8: 2\right]$ showed that the reaction was complete. The reaction mixture was poured onto ice-cold water and extracted with chloroform $(3 \times 15 \mathrm{~mL})$, then dried with anhydrous sodium sulphate, the chloroform layer was evaporated to give a syrup $(0.75 \mathrm{~g}, \quad 84 \%$ yield $), \quad \mathrm{R}_{\mathrm{f}}=0.55$ [CHCl$: \mathrm{MeOH} ; 9: 1]$, FTIR (film) $2200 \mathrm{~cm}^{-1}$ $(\mathrm{CN}), 1714 \mathrm{~cm}^{-1}(\mathrm{C}=\mathrm{O})$.
General method for the synthesis of arylsulfonyl azides:

Arylsulfonyl chloride and excess sodium azide were heated with stirring in acetone $(50 \mathrm{~mL})$. The reaction mixture was monitored by TLC $\left[\mathrm{CHCl}_{3}\right.$ :ethyl acetate; 8:2]. When the reaction was completed, excess of sodium chloride was removed by filtration and evaporation of the organic solvent gave the desired product as solid or oil.

IR spectral data showed a band at $2137 \mathrm{~cm}^{-1}\left(\mathrm{~N}_{3}\right)$ and $1365 \mathrm{~cm}^{-1}, 1170 \mathrm{~cm}^{-1}$ $\left(\mathrm{SO}_{2}\right)$, with the disappearance of $(\mathrm{C}-\mathrm{Cl})$ band at $740 \mathrm{~cm}^{-1}$.

General procedure for cycloaddition reaction of azidosugar with selected alkenes:

Preparation of compounds (5-10):

A mixture of the azidosugar (3) (0.5 g, $0.803 \mathrm{mmol})$ and alkene $(0.803 \mathrm{mmol})$ was heated with stirring in dioxane $(20 \mathrm{~mL})$ and monitored by TLC [benzene:MeOH; 9:1] until it indicated completion of reaction. The mixture was poured onto ice-cold water $(50 \mathrm{~mL})$, then extracted with chloroform $(3 \times 15 \mathrm{~mL})$ and the chloroform of the extract was evaporated to give a syrupy product.

1-(1',3',4',6'-Tetra-O-benzoyl- $\beta-D-$

fructofuranose-2'-yl)-4-carboxy-5-phenyl-1H1,2,3-triazoline (5)

$\mathrm{R}_{\mathrm{f}}=0.41\left[\mathrm{CH}_{2} \mathrm{Cl}_{2}: \mathrm{MeOH} ; 8: 2\right] ;$ IR (film) $3400 \mathrm{~cm}^{-1}(\mathrm{COOH}), 1720 \mathrm{~cm}^{-1}(\mathrm{C}=\mathrm{O})$; UV $\left(\mathrm{CHCl}_{3}\right)\left(\lambda_{\max }, \mathrm{nm}\right): 240,362$.

1-(1',3',4',6'-Tetra-O-benzoyl- $\beta$ - $D$ fructofuranose-2'-yl)-4-formyl-5-phenyl-1H1,2,3-triazoline (6):

$\mathrm{R}_{\mathrm{f}}=0.38 \quad\left[\mathrm{CH}_{2} \mathrm{Cl}_{2}: \mathrm{MeOH} ; 8: 2\right]$; IR (film)

$2800 \mathrm{~cm}^{-1} \quad(\mathrm{C}-\mathrm{H}), 1730 \mathrm{~cm}^{-1} \quad(\mathrm{C}=\mathrm{O}$ of benzoate), $1690 \mathrm{~cm}^{-1} \quad(\mathrm{C}=\mathrm{O}$ of aldehyde); $\mathrm{UV}\left(\mathrm{CHCl}_{3}\right)\left(\lambda_{\max }, \mathrm{nm}\right): 246,370$.

1-(1',3',4',6'-Tetra-O-benzoyl- $\beta$-Dfructofuranose-2'-yl)-4-carboxy-1H-1,2,3triazoline (7):

$\mathrm{R}_{\mathrm{f}}=0.43\left[\mathrm{CH}_{2} \mathrm{Cl}_{2}: \mathrm{MeOH} ; 8: 2\right]$; IR (film) $3450 \mathrm{~cm}^{-1}(\mathrm{COOH}), 1724 \mathrm{~cm}^{-1}(\mathrm{C}=\mathrm{O})$. 
1-(1',3',4',6'-Tetra-O-benzoyl- $\beta$ - $D$ -

fructofuranose-2'-yl)-4-cyano-1H-1,2,3-

triazoline (8):

$\mathrm{R}_{\mathrm{f}}=0.46\left[\mathrm{CH}_{2} \mathrm{Cl}_{2}: \mathrm{MeOH} ; 8: 2\right] ; \mathrm{IR}$ (film) $2220 \mathrm{~cm}^{-1}(\mathrm{CN}), 1715 \mathrm{~cm}^{-1}(\mathrm{C}=\mathrm{O})$.

\section{1-(1',3',4',6'-Tetra-O-benzoyl- $\beta-D-$}

fructofuranose-2'-yl)-4-carbamoyl-1H-1,2,3triazoline (9):

$\mathrm{R}_{\mathrm{f}}=0.3 \quad\left[\mathrm{CH}_{2} \mathrm{Cl}_{2}: \mathrm{MeOH} ;\right.$ 8:2]; FTIR (film) 3354, $3199 \mathrm{~cm}^{-1}\left(\mathrm{NH}_{2}\right), 1724 \mathrm{~cm}^{-1}$ $(\mathrm{C}=\mathrm{O}), 1674 \mathrm{~cm}^{-1}(\mathrm{C}=\mathrm{O}$ amide $)$.

${ }^{1} \mathrm{H}-\mathrm{NMR}\left(\mathrm{CDCl}_{3}\right) \delta(\mathrm{ppm}): 2.89(2 \mathrm{H}, \mathrm{d}$, H-5), 4.4-4.9 (6H, m, H-4, H-6', 6', H-1', 1', H-5'), 5.65-5.82 (2H, m, H-4', H-3'), 5.85$6.05\left(2 \mathrm{H}, \mathrm{m}, \mathrm{NH}_{2}\right), 7.15-8.20(20 \mathrm{H}, \mathrm{m}$, $4 \mathrm{BzO})$.

1-(1',3',4',6'-Tetra-O-benzoyl- $\beta$-Dfructofuranose-2'-yl)-4,5-dicarboxy-1H1,2,3-triazoline (10):

$\mathrm{R}_{\mathrm{f}}=0.28 \quad\left[\mathrm{CH}_{2} \mathrm{Cl}_{2}: \mathrm{MeOH} ; 8: 2\right] ;$ FTIR (film) $3354 \mathrm{~cm}^{-1}(\mathrm{COOH}), 1726 \mathrm{~cm}^{-1}(\mathrm{C}=\mathrm{O})$, $\mathrm{UV}\left(\mathrm{CHCl}_{3}\right)\left(\lambda_{\max }, \mathrm{nm}\right): 233$.

${ }^{1} \mathrm{H}-\mathrm{NMR}\left(\mathrm{CDCl}_{3}\right) \delta(\mathrm{ppm}): 4.2-5.1(5 \mathrm{H}, \mathrm{m}$, H-4, H-5, H-6', 6', H-5'), 5.5-6.1 (4H, m, H-1',1', H-4', H-3'), 7.1-8.2 (20h, m, 4BzO), $10.5(2 \mathrm{H}, \quad \mathrm{s}, \mathrm{COOH}) ;{ }^{13} \mathrm{C}-\mathrm{NMR}\left(\mathrm{CDCl}_{3}\right)$ $\delta(\mathrm{ppm}): 64,65,65.9,67,69$ and $80\left(\mathrm{C}_{6}{ }^{\prime}, \mathrm{C}_{1}{ }^{\prime}\right.$, $\left.\mathrm{C}_{4}^{\prime}, \mathrm{C}_{3}{ }^{\prime}, \mathrm{C}_{5}{ }^{\prime}, \mathrm{C}_{2}{ }^{\prime}\right), 83$ (C-triazole), 128-133 (Caromatic), 166-168.5 ), 176.1, $176.3(\mathrm{COOH})$.

\section{General procedure for Cu-catalyzed} cycloaddition (Click reaction) of some terminal alkynes with azidosugar (3):

Preparation of compounds (12-14):

Compound (3) $(0.1 \mathrm{~g}, 0.161 \mathrm{mmol})$ was dissolved in $(20 \mathrm{~mL})$ of $\left(\mathrm{t}-\mathrm{BuOH}: \mathrm{H}_{2} \mathrm{O} ; 2: 1\right)$ and termial alkyne $(0.161 \mathrm{mmol})$ (propargyl chloride, propargyl alcohol and 1-hexyn-3-ol) was added followed by the addition of $\left(\mathrm{ph}_{3} \mathrm{P}\right)_{3} \mathrm{CuI}(0.1 \mathrm{~g})$ as a catalyst. The mixture was then refluxed with stirring for $20 \mathrm{hrs}$. TLC showed that the reaction was complete. The mixture was poured onto ice-cold water, then extracted with chloroform $(3 \times 15 \mathrm{~mL})$ and the solvent was evaporated to give the triazole as a syrup.
1-(1',3',4',6'-Tetra-O-benzoyl- $\beta$ - $D$ -

fructofuranose-2'-yl)-4-chloromethyl-1H-

1,2,3-triazole (12):

$72 \%$ yield; $\mathrm{R}_{\mathrm{f}}=0.32\left[\mathrm{CH}_{2} \mathrm{Cl}_{2}: \mathrm{MeOH} ; 8: 2\right] ;$ FTIR (film) $1724 \mathrm{~cm}^{-1}(\mathrm{C}=\mathrm{O}), 1600 \mathrm{~cm}^{-1}$ $(\mathrm{C}=\mathrm{C}), 711 \mathrm{~cm}^{-1}(\mathrm{C}-\mathrm{Cl})$.

1-(1',3',4',6'-Tetra-O-benzoyl- $\beta-D-$ fructofuranose-2'-yl)-4-hydroxymethyl-1H1,2,3-triazole (13):

$64 \%$ yield; $\mathrm{R}_{\mathrm{f}}=0.39\left[\mathrm{CH}_{2} \mathrm{Cl}_{2}: \mathrm{MeOH} ; 8: 2\right] ;$ FTIR (film) $3400 \mathrm{~cm}^{-1}(\mathrm{OH}), 1712 \mathrm{~cm}^{-1}$ $(\mathrm{C}=\mathrm{O}), 1604 \mathrm{~cm}^{-1}(\mathrm{C}=\mathrm{C})$.

1-(1',3',4',6'-Tetra-O-benzoyl- $\beta-D-$

fructofuranose-2'-yl)-4-(1-hydroxybutyl)-1H1,2,3-triazole (14):

$52 \%$ yield; $\mathrm{R}_{\mathrm{f}}=0.28 \quad\left[\mathrm{CH}_{2} \mathrm{Cl}_{2}: \mathrm{MeOH} ;\right.$ 8:2]; FTIR (film) $3460 \mathrm{~cm}^{-1}(\mathrm{OH}), 1715 \mathrm{~cm}^{-1}$ $(\mathrm{C}=\mathrm{O}), 1615 \mathrm{~cm}^{-1}(\mathrm{C}=\mathrm{C})$.

General procedure for cycloaddition of cyanosugar (4) with arylsulfonyl azides:

Preparation of compounds (16-18):

The cyanosugar (4) (0.2 g, $0.253 \mathrm{mmol})$ was dissolved in toluene $(20 \mathrm{~mL})$ and arylsulfonyl azide $(0.253 \mathrm{mmol})$ was added. The mixture was heated at $\left(70-75^{\circ} \mathrm{C}\right)$ in an oilbath for $90 \mathrm{hrs}$. TLC $\left[\mathrm{CH}_{2} \mathrm{Cl}_{2}: \mathrm{MeOH} ; 8: 2\right]$ indicated the completion of the reaction. The mixture was poured onto ice-cold water and extracted with chloroform $(3 \times 15 \mathrm{~mL})$. The organic layer was dried with anhydrous $\mathrm{Na}_{2} \mathrm{SO}_{4}$, then the solvent was evaporated to give a syrup, which was purified on a column of silica-gel using $\left[\mathrm{CH}_{2} \mathrm{Cl}_{2}\right.$ :Ethyl acetate; 8:2] as eluent.

\section{2-(Benzenesulfonyl)-5-(1',3',4',6'-tetra-O-}

benzoyl- $\beta$-D-fructofuranose-2'-yl)-2H-

tetrazole (16):

$59 \%$ yield; $\mathrm{R}_{\mathrm{f}}=0.24,0.18\left[\mathrm{CH}_{2} \mathrm{Cl}_{2}\right.$ : Ethyl acetate; 9:1]; IR (film) $1725 \mathrm{~cm}^{-1}(\mathrm{C}=\mathrm{O})$, $1610 \mathrm{~cm}^{-1}(\mathrm{C}=\mathrm{N}), 1372,1160 \mathrm{~cm}^{-1}\left(\mathrm{SO}_{2}\right)$ and 1135,1085 and $1030 \mathrm{~cm}^{-1}$ for the tetrazole ring.

\section{2-(p-Toluenesulfonyl)-5-(1',3',4',6'-tetra-O-}

benzoyl- $\beta-D$-fructofuranose-2'-yl)-2H-

tetrazole (17):

$77 \%$ yield; $\mathrm{R}_{\mathrm{f}}=0.2,0.15\left[\mathrm{CH}_{2} \mathrm{Cl}_{2}\right.$ : Ethyl acetate; 8:2]; IR (film) $1715 \mathrm{~cm}^{-1}(\mathrm{C}=\mathrm{O}), 1380$, $1172 \mathrm{~cm}^{-1}\left(\mathrm{SO}_{2}\right), 1612 \mathrm{~cm}^{-1}(\mathrm{C}=\mathrm{N}), 1130$, 1090 and $1040 \mathrm{~cm}^{-1}$ for tetrazole. 
${ }^{1} \mathrm{H}-\mathrm{NMR}\left(\mathrm{CDCl}_{3}\right) \quad \delta(\mathrm{ppm}): 2.4(3 \mathrm{H}, \mathrm{s}$, $\left.\mathrm{CH}_{3}\right), 4.95$ (2H, H-6', 6'), 5.15 (2H, s, H-1', 1'), $5.38\left(1 \mathrm{H}, \mathrm{H}-5^{\prime}\right), 5.59\left(1 \mathrm{H}, \mathrm{d}, \mathrm{H}-4^{\prime}\right), 5.88$ (1H, d, H-3'), 7.40-8.15 (24H, m, 4BzO, Ar); ${ }^{13} \mathrm{C}-\mathrm{NMR}\left(\mathrm{CDCl}_{3}\right) \delta(\mathrm{ppm}): 20.5\left(\mathrm{CH}_{3}\right), 58.2$, 65.15, 69.0, 71.12, 76 and $85\left(\mathrm{C}_{4}{ }^{\prime}, \mathrm{C}_{5}{ }^{\prime}, \mathrm{C}_{6}{ }^{\prime}, \mathrm{C}_{1}{ }^{\prime}\right.$, $\mathrm{C}_{3}{ }^{\prime}$ and $\mathrm{C}_{2}{ }^{\prime}$ ), 128.5-135.6 (C-aromatic), 137 $\left(\mathrm{C}-\mathrm{SO}_{2}\right), 138\left(\mathrm{Ar}-\mathrm{CH}_{3}\right), 151.3(\mathrm{C}=\mathrm{N}), 165-$ $167\left(\stackrel{\mathrm{C}^{-} \mathrm{Bz}}{\mathrm{O}}\right)$.

2-(m-Nitrobenzenesulfonyl)-5-(1',3',4',6'tetra-O-benzoyl - $\beta$-D-fructofuranose-2'-yl)2H-tetrazole (18):

$57 \%$ yield; $\mathrm{R}_{\mathrm{f}}=0.19,0.14\left[\mathrm{CH}_{2} \mathrm{Cl}_{2}\right.$ : Ethyl acetate; 9:1]; FT-IR (film) $1728 \mathrm{~cm}^{-1}(\mathrm{C}=\mathrm{O})$, $1602 \mathrm{~cm}^{-1}(\mathrm{C}=\mathrm{N}), 1352,1176 \mathrm{~cm}^{-1}\left(\mathrm{SO}_{2}\right)$, 1533, $1379 \mathrm{~cm}^{-1}\left(\mathrm{NO}_{2}\right)$, for tetrazole 1122 , 1097 and $1070 \mathrm{~cm}^{-1}$.

\section{2,5-Bis $\left(1^{\prime}, 3^{\prime}, 4^{\prime}, 6^{\prime}\right.$-tetra-O-benzoyl- $\beta$-D- fructofuranos-2'-yl)-2H-tetrazole (20):}

The azidosugar (3) $(0.1 \mathrm{~g}, 0.151 \mathrm{mmol})$ was dissolved in $(20 \mathrm{~mL})$ of toluene and cyanosugar (4) $(0.1 \mathrm{~g}, 0.165 \mathrm{mmol})$ was added. The mixture was heated at $\left(60-70{ }^{\circ} \mathrm{C}\right)$ with continuous stirring for $40 \mathrm{hrs}$. TLC $\left[\mathrm{CHCl}_{3}: \mathrm{MeOH} ; 9: 1\right]$ showed that the reaction was complete. The mixture was poured onto ice-cold water, then extracted with chloroform $(3 \times 15 \mathrm{~mL})$. The organic layer was dried with anhydrous $\mathrm{Na}_{2} \mathrm{SO}_{4}$, then evaporated to give a syrup $(0.07 \mathrm{~g}, 35 \%$ yield); $\mathrm{R}_{\mathrm{f}}=0.12 \quad\left[\mathrm{CH}_{2} \mathrm{Cl}_{2}: \mathrm{MeOH} ; 8: 2\right] ; \mathrm{IR}$ (film) $1730 \mathrm{~cm}^{-1}(\mathrm{C}=\mathrm{O}), 1610 \mathrm{~cm}^{-1}(\mathrm{C}=\mathrm{N})$.

General procedure for hydrolysis of benzoate groups in triazole, triazoline and tetrazole derivatives:

The benzolayted compound $(0.1 \mathrm{~g})$ in $(0.01 \mathrm{M})$ methanolic sodium methoxide $(20 \mathrm{~mL})$ was refluxed with stirring for $1.5 \mathrm{hrs}$. Neutralization with amberlite $\operatorname{IR}(120)\left(\mathrm{H}^{+}\right)$ resin was achieved and the mixture was filtered. The filtrate was evaporated to dryness and the product was purified by a column of silica-gel 60 . The column was eluted with $\left[\mathrm{CHCl}_{3}: \mathrm{MeOH} ; 8: 2\right]$. The major fraction was evaporated to give an amorphous powder.
1-( $\beta$-D-fructofuranos-2'-yl)-4,5-dicarboxy-

1H-1,2,3-triazoline (11):

M.p. $\left(190-193{ }^{\circ} \mathrm{C}\right) ; 72 \%$ yield; $\mathrm{R}_{\mathrm{f}}=0.3$ $\left[\mathrm{CH}_{2} \mathrm{Cl}_{2}: \mathrm{MeOH} ; \quad 8: 2\right] ; \quad$ IR $\quad(\mathrm{KBr}$ disc) $3300 \mathrm{~cm}^{-1}(\mathrm{OH}$ of $\mathrm{COOH}), \quad \mathrm{UV}\left(\mathrm{H}_{2} \mathrm{O}\right)$ $\left(\lambda_{\max }, \mathrm{nm}\right): 317$.

1-( $\beta$-D-fructofuranos-2'-yl)-4-(butyl-1-ol)-1H1,2,3-triazole (15):

M.p. $\left(200-203{ }^{\circ} \mathrm{C}\right) ; 75 \%$ yield; $\mathrm{R}_{\mathrm{f}}=0.46$ $\left[\mathrm{CHCl}_{3}: \mathrm{MeOH} ; 6: 4\right]$; IR (KBr disc) $3440 \mathrm{~cm}^{-1}$ $(\mathrm{OH})$.

\section{2-(m-Nitrobenzenesulfonyl-5-( $\beta-D-$}

fructofuranos-2'-yl)-2H-tetrazole(19):

M.p. $\left(182-184{ }^{\circ} \mathrm{C}\right) ; 68 \%$ yield; $\mathrm{R}_{\mathrm{f}}=0.35$ [CHCl 3 : $\mathrm{MeOH} ; 5: 5]$; IR ( $\mathrm{KBr}$ disc) $3350 \mathrm{~cm}^{-1}$ $(\mathrm{OH}), 1360,1180 \mathrm{~cm}^{-1}\left(\mathrm{SO}_{2}\right), 1602 \mathrm{~cm}^{-1}$ $(\mathrm{C}=\mathrm{N})$.

\section{2,5-Bis( $\beta$-D-fructofuranos-2'-yl)-2H-tetrazole (21):}

M.p. $\left(212-215{ }^{\circ} \mathrm{C}\right) ; 80 \%$ yield; $\mathrm{R}_{\mathrm{f}}=0.23$ $\left[\mathrm{CH}_{2} \mathrm{Cl}_{2}: \mathrm{MeOH} ; 6: 4\right]$; FT-IR ( $\mathrm{KBr}$ disc) $3433 \mathrm{~cm}^{-1}(\mathrm{OH}), 1600 \mathrm{~cm}^{-1}(\mathrm{C}=\mathrm{N})$.

\section{References}

[1] Y.S. Sanghvi, B.K. Bhatta Charya, G.D. Kini and S.S. Matsumoto, J. Med. Chem., 33 (1990) 336.

[2] G. Biagi, I. Giorgi, O. Livi and A. Lucacchini, J. Pharm. Sci., 82 (1993) 893.

[3] A. Bascal, L. Holden-Dye, R.J. Willis and S.W.G. Smith, J. Parasitolgy, 112 (1996) 253.

[4] C. Peto, G. Batta, Z. Gyorgdeak and F. Szaricskai, J. Carbohyd. Chem., 15 (1996) 465.

[5] G.S. Gadaginamath, S.A. Patil and A.S. Shydligeri, Ind. J. Chem., 35(B) (1996) 681684.

[6] M.M. Pearson, P.D. Rogers and S.W. Chapman, Ann. Pharmacother., 37(3), (2003) 420-32.

[7] C.H. Chu, X.W. Sun, L. Sun and Z.Y. Zhang, J. Chin. Chem. Soc., 46 (1999) 229.

[8] P.K. Kadaba, P.J. Stevenson and P. Nunane, Bio Org. Med. Chem., 4(2) (1996) 165.

[9] A.M.S. Abdennabi, A.I. Abdalhadi and S.T. Abu-Orabi, Anti Corrosion Methods and Materials, 45 (1998) 103. 
[10] S.T. Abu-Orabi, Molecules, 7 (2002) 302314.

[11] Sergey A. Nepogodiev, Simone Dedola, Laurence Marmuse, Marcelo T. de Oliveira and Robert A Field, Carbohydrate Research 342, (2007) 529-540.

[12] G.I. Koldaskii and V.A. Ostrovskii, Khim. Geterotsikl. Soedin, 6 (1985) 557-858.

[13] G.I. Koldoskii, V.A. Ostrovskii and V.S. Poplavskii, Advances in Tetrazole's Chemistry (Review), Khim. Geterotsikl. Soedin, 10, (1981) 1299-1326.

[14] G.D. Chaitanya and R.D. Shah, Molecules, 7 (2002) 554-565.

[15] T. Himanshui, R. Olsen-Carl-E and P. Ashok-K, Bio. Org. Med. Chem., 10(4), (2002) 963-8.

[16] P.K. Kadabe and M.M. Morgan, Bio. Med. Pharamacother., 49(7-8) (1995) 381.

[17] A.A Jarrahoup, M. Shekarriz and A. Taslimi, Molecules ,9 (2004), 29-38.

[18] P. Brigl and R. Schinle, Ber., 67 (1934) 754.

[19] R.M. Silverstein, G.C. Basler and T.C. Morril, "Spectroscopic identification of Organic Compounds", John Wiely and Sons, Inc., New York, $4^{\text {th }}$ Ed. (1980).

[20] V.V. Rostovtsev, L.G. Freen, V.V. Fokin and K.B. Sharpless, Angew. Chem. Int. Ed., 2002, 114, 2708-2711.

[21] M.M. Ismail, M. Abass and M.M. Hassan, Fourth International Electronic Conferences on Synthetic Organic Chemistry (ECSOC-4), www.mdpi.org/escoc40htm, September, 130 (2000).

[22] R. Huisgen, J.Org. Chem., 33 (1968) 2291-2297.

[23] M.R. Atlas, E. Alfres, Brown and C. Lawrence Parks, "Laboratory Manual Experimental Microbiology, Mosby-Year Book Inc. (1995).

[24] R.K. Ness and H.G. Fleteher, J. Am. Chem. Soc., 75 (1953) 2619.

[25] Taken in part from ph.D. thesis of F. W. Askar, Al-Mustansirya University, Baghdad.
يتضمن هذا العمل تحضير مشتقات كاربوهيدراتيـة جديدة

تحتـوي حلقـة 3,2,1-ترايـازول، 3,2,1-ترايـازولين و حلقـة تثرازول بطريقة تقاعل الاضافة ثتائية القطب 1 و 3 الحلقية. للحصـول على هـذه المشـتقات، حضـر 1، 3، 4، 6-

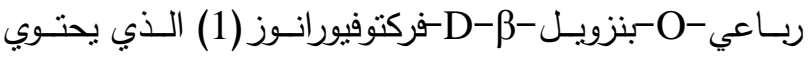
على مجموعة هيدروكسيل حرة في الموقع -2-كمادة اولية. عند معاملة (1) مـع (HBr 45\%) المذاب في حامض

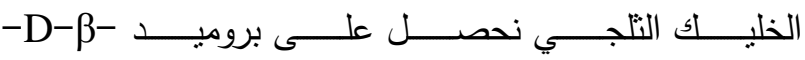
فركتوفيورانوسيليل(2)، بعد ذلك تم مفاعلـة (2) مـع عدد مـن الكواثـف الباحثة عـن النـواة مثل ازيـــ الصـوديوم، و سـيانيد

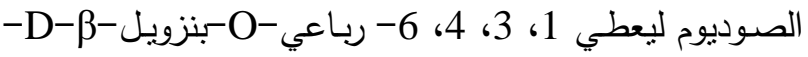

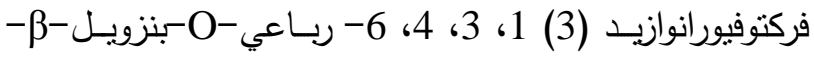
فركتوفيورانوسـيانيد (4). عنــد معاملـة (3) مسـع حـامض -D السينامك, سينمالديهايد, حامض الاكريليك, اكريليك نايتريل,

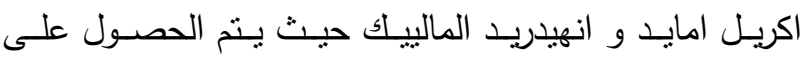
مشتقات الترايزولين(5-10).

و عنــد اجـراء تفاعـل الاضــافة الحلقيـة 1و 3 بـين ازيـــ

السـكر (3) و كلوريـد البروبرجيـل و كحـول البروبرجيـل و 1هيكساين -3-اول, باستخدام (ph3P)3CuI) كعامل مساعد تم الحصـول على مشتقات الترايزول(12-14). تفاعل سيانيد السكر (4) مـع اريـل سلفونيل ازايد اعطى عدد من مشتقات النتقازول (16-18).

تـــم تقـــويم الفعاليــة المضــــادة للبكتريـــا و الفطريـــات

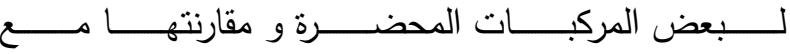
نــــوعين مــــن المضـــــادات الامبســـلين و جنتاميســـين - (Ampicillin and Gentamycin) 